\title{
Imaging features of toxic megacolon
}

\author{
Sidney Ching Liang Ong, ${ }^{1}$ Nadiah Mohaidin ${ }^{2}$
}

${ }^{1}$ Radiology Department, Clinical Campus, International Medical University, Seremban, Negeri Sembilan, Malaysia ${ }^{2}$ Department of Diagnostic Imaging, Hospital Tuanku Ja'afar Seremban, Seremban, Malaysia

\section{Correspondence to} Dr Sidney Ching Liang Ong, sidney_ong@yahoo.co.uk

Accepted 20 September 2018

\section{DESCRIPTION}

A 27-year-old woman presents with vomiting and abdominal pain for 2 days. She had been diagnosed with ulcerative colitis (UC) 2 weeks prior and was started on oral sulfasalazine and prednisolone. Currently, she is afebrile and not tachycardic. On examination, the abdomen was distended and tender centrally. Serial abdominal radiographs showed persistently dilated transverse colon with loss of haustra (figure 1). CT abdomen revealed diffuse bowel thickening involving the ascending colon, caecum and terminal ileum with multiple pseudopolyps at the ascending colon (figure 2). The transverse colon is dilated up to $6.8 \mathrm{~cm}$ (figure 3 ). There are also multiple enlarged right-sided mesenteric nodes. A diagnosis of toxic megacolon (TM) was made. She deteriorated during admission due to acute pulmonary embolism. Blood investigations showed marked leucocytosis $\left(32 \times 10^{9} / \mathrm{L}\right)$ and raised C-reactive proteins $(98.7 \mathrm{mg} / \mathrm{L})$. Subtotal colectomy involving the caecum until splenic flexure was performed followed by ileostomy and mucous fistula. Her clinical symptoms improved remarkably following surgery and she was discharged well within a week.

TM is a potentially fatal complication of severe colitis. It is defined as a segmental or total colonic

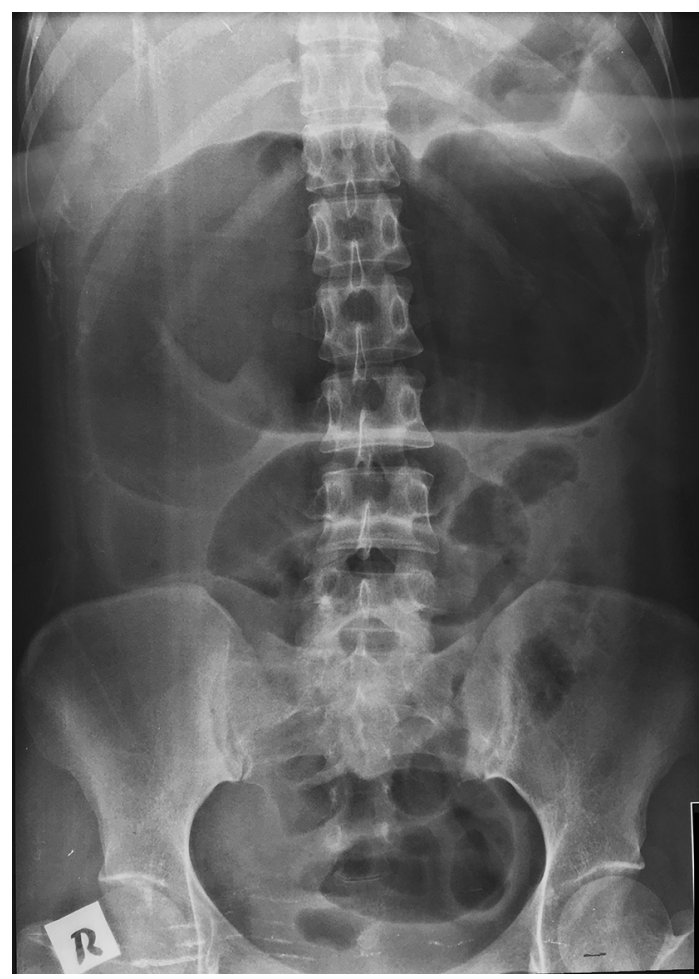

Figure 1 Plain abdominal radiograph showed a grossly dilated ahaustral transverse colon.

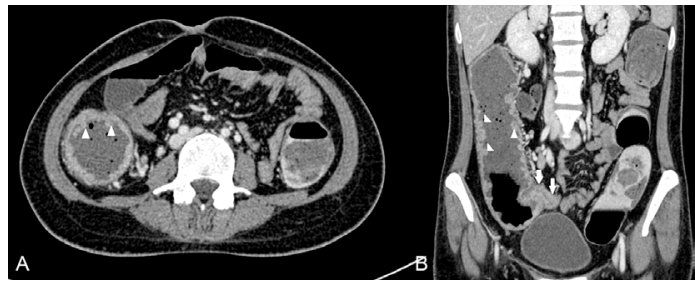

Figure 2 Contrast-enhanced CT abdomen in axial (A) and coronal (B) sections showed irregularly thickened ascending colon and caecum. Multiple pseudopolyps (arrowheads) seen projecting into the lumen. The terminal ileum was also thickened (arrows).

distension of $>6 \mathrm{~cm}$ in the presence of acute colitis and signs of systemic toxicity. Although any cause of colitis increases the risk of TM, UC is the most associated predisposing factor. TM is present in up to $10 \%$ of all UC admission. In earlier reviews, mortality rates vary from $19 \%$ to $27 \%$ with up to fivefold increase in mortality rate in case of perforation. ${ }^{2}$ In 2018, however, Doshi et al found that all-cause in-hospital mortality was $7.9 \% .^{2} \mathrm{Up}$ to $57 \%$ of those who undergo medical therapy will eventually require colectomy. ${ }^{13}$ Clostridium difficile is the most commonly associated infectious pathogen (76\%) and its presence can further complicate TM. ${ }^{2}$ Unfortunately, stool culture and toxin assays were not performed for our patient.

Clinical features of TM are often preceded by signs and symptoms of colitis. Patients may experience bloatedness, abdominal distension and constipation-as such, antimotility medications are contraindicated. Blood results may show elevated leucocytosis and anaemia. Radiographically, the transverse colon is often dilated due to its anterosuperior position and a diameter of $>6 \mathrm{~cm}$ is highly suspicious. 'Thumbprinting sign' may be present. CT findings will highlight the extent of involvement (colonic submucosal oedema, pseudopolyps, ahaustral pattern, dilatation), adjacent inflammation (mesenteric fat stranding) and other associated

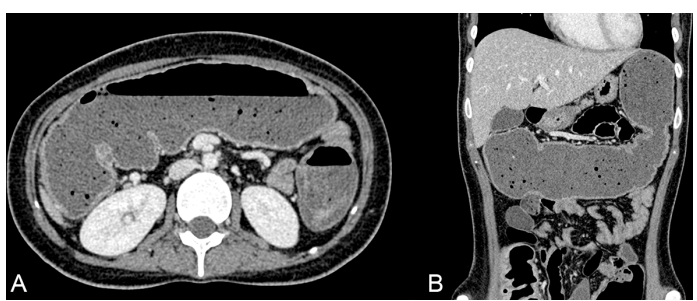

Figure 3 Contrast-enhanced $\mathrm{CT}$ abdomen in axial (A) and coronal (B) sections confirmed the diffuse dilatation of transverse colon up to $6.8 \mathrm{~cm}$ in diameter. The mural thickening was less extensive than ascending colon but nevertheless appeared irregular with absent haustra. 
features (ascites, abscesses, small bowel involvement). Although CT findings facilitate further management, there are no specific features to suggest the underlying cause or clinical outcome of TM. $^{3}$

Management is divided into supportive, medical and surgical therapy. Supportive care includes optimising fluid regime, bowel rest or decompression and discontinuation of aggravating drugs. Medical therapy is targeted at the underlying cause of TM-corticosteroids in UC, antibiotics in treating organism-induced TM to reduce mortality if perforation occurs. Absolute indications

\section{Learning points}

Diagnosis of toxic megacolon (TM) is made based on constellation of clinical, laboratory and imaging findings.

- Any cause of colitis can lead to TM, but ulcerative colitis is often the culprit.

- Medical therapy can be initiated but surgical resection must be performed if the patient is deteriorating or not showing signs of improvement. for surgery include perforations, uncontrollable bleeding and progressive dilatation. Surgical resections result in rapid clinical improvement, and as such is recommended by some experts to be performed as soon as diagnosis is made. Nevertheless, trial of medical therapy can be initiated first. ${ }^{1}$

Contributors SCLO and NM have contributed sufficiently to the project and have met all criteria to be included as authors.

Funding The authors have not declared a specific grant for this research from any funding agency in the public, commercial or not-for-profit sectors.

Competing interests None declared.

Patient consent Obtained.

Provenance and peer review Not commissioned; externally peer reviewed.

\section{REFERENCES}

1 Gan SI, Beck PL. A new look at toxic megacolon: an update and review of incidence, etiology, pathogenesis, and management. Am J Gastroenterol 2003;98:2363-71.

2 Doshi R, Desai J, Shah Y, et al. Incidence, features, in-hospital outcomes and predictors of in-hospital mortality associated with toxic megacolon hospitalizations in the United States. Intern Emerg Med 2018;13:881-7.

3 Imbriaco M, Balthazar EJ. Toxic megacolon: role of CT in evaluation and detection of complications. Clin Imaging 2001;25:349-54.

Copyright 2018 BMJ Publishing Group. All rights reserved. For permission to reuse any of this content visit

http://group.bmj.com/group/rights-licensing/permissions.

BMJ Case Report Fellows may re-use this article for personal use and teaching without any further permission.

Become a Fellow of BMJ Case Reports today and you can:

- Submit as many cases as you like

- Enjoy fast sympathetic peer review and rapid publication of accepted articles

- Access all the published articles

Re-use any of the published material for personal use and teaching without further permission

For information on Institutional Fellowships contact consortiasales@bmjgroup.com

Visit casereports.bmj.com for more articles like this and to become a Fellow 